\title{
Behavioral assessment of cell transplantation after focal cerebral ischemia in rats
}

\author{
Tae Hoon Lee* \\ Department of Emergency Medical Service, Namseoul University, Cheonan, Korea
}

We induced middle cerebral artery occlusion (MCAO) in rats using silicone-coated vascular embolus. We transplanted mouse embryonic stem (mES) cells after MCAO. Rats were tested behaviorally using motor and sensory function with neurological assessment. Functional effectiveness of the transplanted $\mathrm{mES}$ cells gradually improved the function of sensory and motor neurons. This study demonstrated that the transplanted cells have synaptic connection in the recipient brain. We suggest that stem cell transplantation can have a positive effect on behavioral recovery and reduction of infarct size in focal ischemic rats. Cell transplantation may induce certain functional recovery of the brain tissue by endogenous cell mediated effect. Our study suggests that intracerebrally injected $\mathrm{mES}$ cells survived and migrated into the infarct area from inoculation site and neuroglially differentiated in the ischemic brain area of adult rats. Therefore, mES cells may be a useful tool for the treatment in neurological diseases. In conclusion, cell transplantation therapy represents a novel approach that may enhance the efficacy and effectiveness of stem cell transplantation after ischemic stroke.

Keywords: Infarct, Mouse embryonic stem cell, Motor neuron, Sensory neuron, Transplanation, Ischemic stroke

\section{INTRODUCTION}

Cerebral ischemia model induces a severe damage of neuron, and it causes behavioral dysfunction in rats (Arvidsson et al 2002; Zuk et al., 2001). The criteria of functional recovery in stroke patients being the main issue, this gradual enlargement of infarction can be limited by a variety of interventions that do not interfere with cerebral blood flow. Therefore, we performed an analysis to investigate the evolution of infarct after middle cerebral artery occlusion (MCAO). We induced this analysis in rats, a model system that has been less well characterized. In order to analyze the changes following transient MCAO, several different histochemical methodologies can be utilized. 2,3,5-Triphenyltetrazolium chloride (TTC) staining is one of the most common histochemical stains used to assess cerebral injury. In ischemic tissue, lack of TTC staining is considered infracted with white color and defined as core and viable tissue is stained red (Iihoshi et al., 2004; Jin et al., 2005; Kim et al., 2007).
We examined the effects of the transplantation of mouse embryonic stem (mES) cells on behavioral function induced by focal ischemia in rats. Stem cell transplantation has established as a potential effective therapy for CNS disorders such as ischemic stroke and spinal cord injury. Embryonic stem (ES) cells are capable of proliferating and differentiation into neural progenitor cells with the use of induction protocols leading to the development of functionally mature neurons and glial cells (Barone and Feuerstein, 1999). Self-renewing, totipotent ES cells may use a virtually unlimited donor source for tissue transplantation (Benedek et al., 2006). We have focused on determining the appropriate culture condition to induce neural cell differentiation of ES cells with good cell viability. A cell based-therapy may have the advantage of exerting multiple therapeutic effects at various sites and times within the lesion as the cells respond to a particular pathological microenvironment. A single injection of $\mathrm{mESC}$ s several hours after ischemia onset can reduce infarction size and improve functional outcome in rodent cerebral ischemia models (Chiba et al., 2004;
${ }^{*}$ Corresponding author: Tae Hoon Lee

Department of Emergency Medical Service, Namseoul University, 91 Daehak-ro, Seonghwan-eup, Cheonan 331-707, Korea

Tel: +82-41-580-2732, Fax: +82-41-580-2935, E-mail: thlee@nsu.ac.kr

Received: May 15, 2015 / Accepted: June 8, 2015
This is an Open Access article distributed under the terms of the Creative Commons Attribution Non-Commercial License (http://creativecommons.org/licenses/by-nc/3.0/) which permits unrestricted non-commercial use, distribution, and reproduction in any medium, provided the original work is properly cited. 
Englund et al., 2002). Endogenous neurogenesis and migration of precursor cells may help to replace some lost neurons in brain structures such as striatum (Ide et al., 1999). Transplantation of embryonic stem cells remains to be the most liable way to repair the massive damage in the cerebral cortex after ischemic stroke. Previous studied suggested that stem cell therapy is a powerful method for neurological disorders (Ikeda et al., 2005). We evaluated whether mES cells transplantation reduces the infarct size with functional improvement in the experimental models.

\section{MATERIALS AND METHODS}

\section{Animal model}

Rat with MCAO were randomly assigned to one of two groups: PBS-only injection group (group $\mathrm{A}, \mathrm{n}=18$ ) and mESC transplantation group (group B, $\mathrm{n}=18$ ).

\section{Preparation of mouse embryonic cell}

ES cell cultures were prepared from stocks of an ES cell line (D3 cells from Dr. D. Gottlieb, Washington University in St. Louis, MO, USA) maintained in our laboratory. Not more than 40 passages were used for experiments. Cells were then plated on poly-D-lysine (PDL) and laminin coated 35-mm glass bottom dishes for imaging studies or 24-well plates in preparation for serum deprivation (SD) experiments.

\section{Cerebral ischemic model}

This study was approved by the animal care and use committee of Namseoul university (Approved No. NSU-14-09), and all procedures were carried out in accordance with institutional guidelines. We induced permanent MCAO by using a previously described method of intraluminal vascular occlusion. Adult female

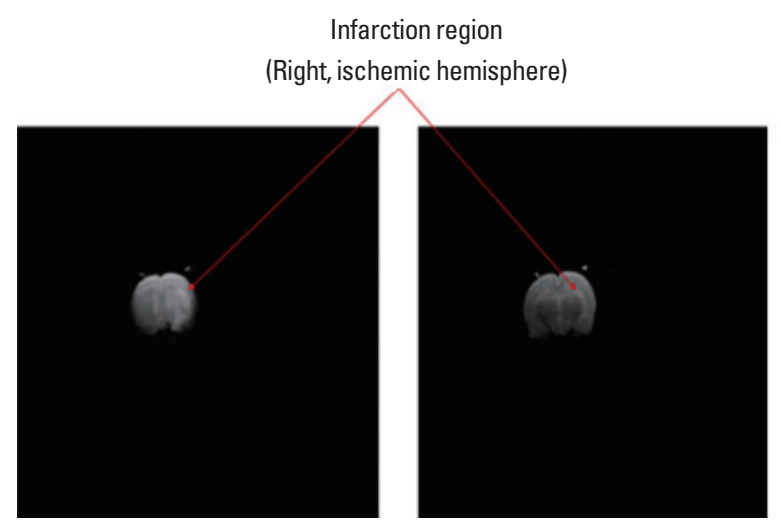

Sprague-Dawley rats $(\mathrm{n}=36)$ weighing 250-300 g were anesthetized with an intrapenitoneal (i.p.) injection of ketamine $(75 \mathrm{mg} /$ $\mathrm{kg}$ ) and xylazine $(10 \mathrm{mg} / \mathrm{kg})$. We induced transient left middle cerebral artery occlusion (MCAO) for $120 \mathrm{~min}$ as previously described (Kunlin et al., 2010). After the occlusion for $30 \mathrm{~min}$, the filament was withdrawn.

\section{Transplantation procedure and staining}

After anesthesia with an intraperitoneal injection of ketamine hydrochloride $(90 \mathrm{mg} / \mathrm{kg}$ ), the rats were given 10.0 - $\mu \mathrm{L}$ deposits of suspended cells $\left(1 \times 10^{5}\right.$ cells per $\mu \mathrm{L}$, or $1.0 \mu \mathrm{L}$ of buffer vehicle only) along the anterior-posterior axis into the target brain at these coordinates: from the bregma, $1.5 \mathrm{~mm}$ laterally and to 3 $\mathrm{mm}$ depth. Rats were euthanized at 28 days of reperfusion. The brains were chilled at $-80^{\circ} \mathrm{C}$ for 4 min to slightly harden the tissue. Five, 2-mm coronal sections were made from the olfactory bulb to the cerebellum and then stained with $1.5 \%$ TTC (Sigma, St. Louise, MO, USA). The stained brain sections were captured with a digital camera. GFP-gene transfection to $\mathrm{mES}$ cells were detected in vitro using a fluorescence microscope.

\section{Statistical analysis}

Quantitative data were expressed as mean \pm SEM. Two-way ANOVA and Student's t-test with the Bonferroni correction for multiple pair-wise comparisons were used for statistical analysis. $P$-values $<0.05$ were considered significant.

\section{RESULTS}

\section{fMRI characteristics of infarction region}

White color of infarction region was shown mainly in corpus callosum and striatum. Fig. 1 shows severe inflammation of in-

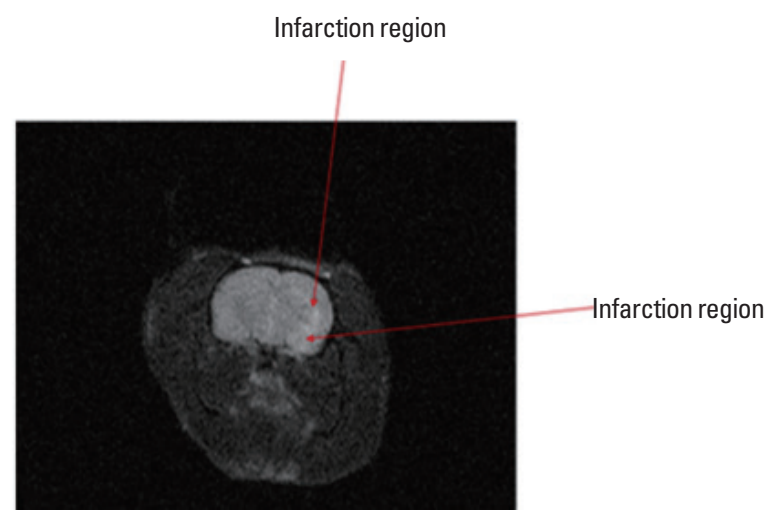

Fig. 1. Morphological features of mES cells showed green fluorescence in vitro (Left and middle: X-100 magnification, Right: X-200 magnification). 
farction site with cytotoxic edema in day 5 after MCAO. AMR imaging technique by diffusion coefficient can be recognized specific infarction region in vitro.

\section{Localization of ischemic lesion}

Normal brain (gray matter) tissue typically stains with TTC, but infarcted lesions show no or reduced staining. TTC staining obtained 4 weeks after MCAO without cell transplantation is shown in Fig. 2A. Fig. 2A showed the reduced TTC staining of the infarction lesion side primarily in the corpus striatum. There were a vivid red staining region and a progressive reduction in infarction size with $\mathrm{mESC}$ treatment in Fig. 2B. Intracerebral delivery of mESCs resulted in very substantial reduction in lesion volume as estimated from TTC staining. Cell treatment reduces MCAO-induced brain infarction. Representative TTC stained brain sections are shown where rats were injected with PBS $(\mathrm{A} ; \mathrm{n}=18)$ or $\mathrm{mESC}$
(B; $\mathrm{n}=18$ ) after MCAO. Animals were killed 28 days later after $\mathrm{MCAO}$ and the brains were sliced into $2 \mathrm{~mm}$ sections and stained with 2,3,5-triphenyltetrazolium chloride (TTC). Different volumes in infarcted region of brains from PBS and $\mathrm{mESC}$ treated animals are shown in the Fig. $2 \mathrm{~A}$ and $2 \mathrm{~B}$ respectively.

\section{Assessment of behavioral function}

Neurological severity scores (NSS) were calculated based on a series of motor, sensory, reflex, and balance tests (Lee and Yoon, 2008). Rats that received PBS show a little behavioral improvement, while transplantation of mESCs transplanted already displayed an early beneficial effect on NSS function and performed significantly better than the control group (Fig. 3). Thus, cell-tranplanted group conferred accelerated recovery in a number of sensorimotor activities. By 28 days after transplantation, group that received mESCs performed significantly better compared to control rats.
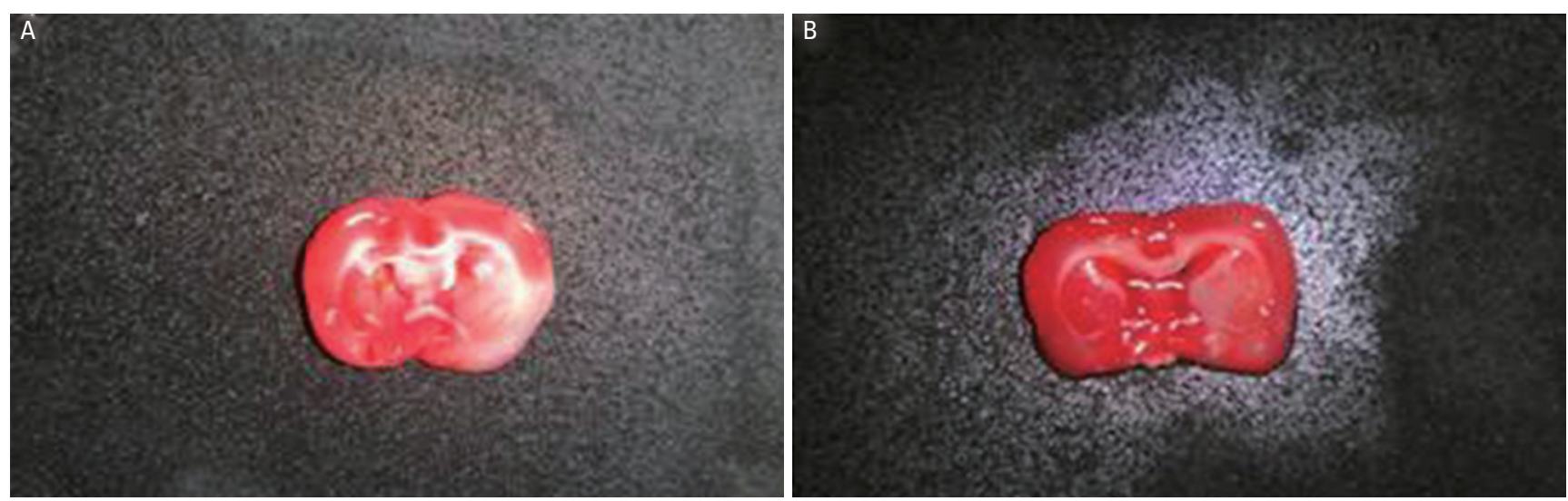

Fig. 2. TTC-staining from PBS treated group (A) and mESC treated group (B).
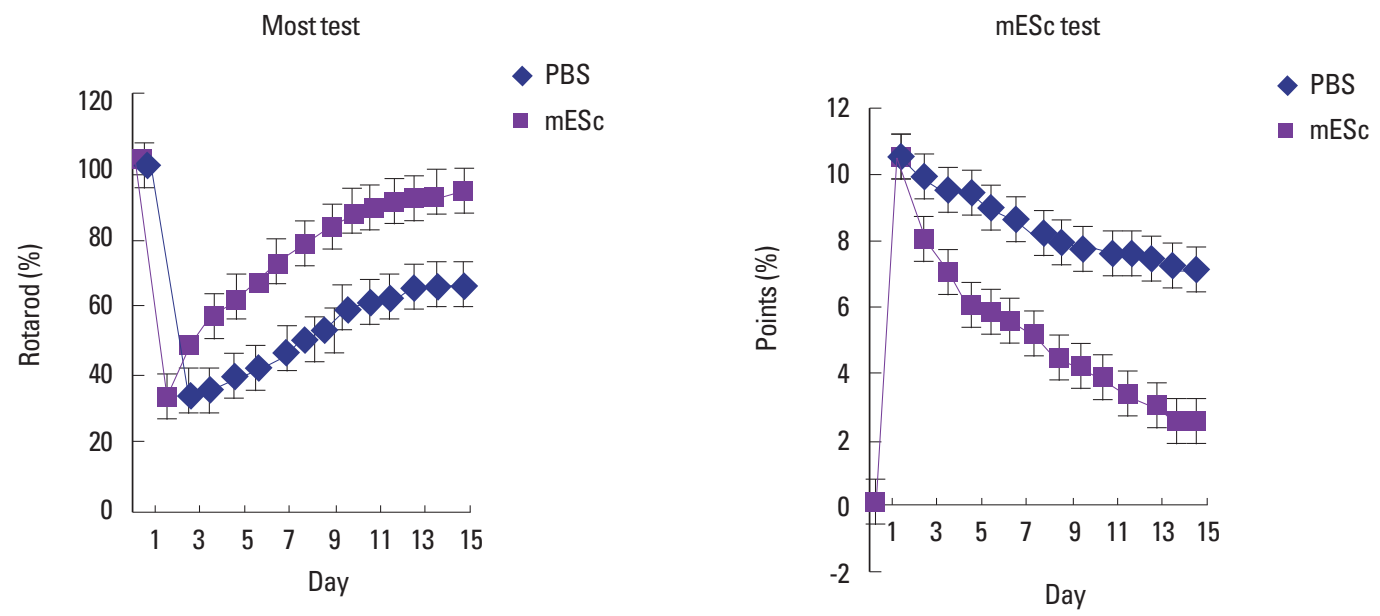

Fig. 3. Behavioral index was tested with PBS treated group and mESCs treated group. 


\section{DISCUSSION}

Stem cell transplantation can restore function in rodent models of diabetes, immunodeficiency, and myocardial infarction, by stimulating the production of pancreatic b-cells, lymphocytes, or endothelial cells from endogenous precursors. It has been reported that transplantation of mouse ES cells into rat brain following experimental stroke reduced infarct volume and improved behavioral outcome (Kim et al., 2007). In the present study, it is reported that transplantation also stimulated neurogenesis in the SVZ ipsilateral to stroke (Lin et al., 1998). Because the magnitude of the inflammatory response and its harmful effects as well as the types of released cytokines change with time after ischemia (Liu et al., 2009; Modo et al., 2000). The timing of the transplant could significantly influence graft survival, and longer survival could be predicted if cells are transplanted once inflammation has subsided. The present study shows that transplantation of mESC not only increased early survival of transplanted cells but also accelerated behavioral recovery following stroke. This is consistent with previous report that grafted embryonic stem cells develop into functional neurons and could integrate into host cortical circuitry (Nakatomi et al., 2002; Omori et al., 2008; Theus et al., 2008). The functional recovery 7 days after transplantation suggests the therapeutic advantage of accelerated repair processes and functional restoration.

The motor functional benefit, however, was more persistent in mESC transplantation, showing much better performance than control animals at 28 days after MCAO. More long-term investigation may be needed to verify the persistence of the morphological and functional benefits of the transplantation strategy (Barone and Feuerstein, 1999). Our finding showed that the infarct size was significantly reduced in both cell-transplanted groups and the post-ischemic exercise group, compared with the sham-operated group. Although the basis for the propagation of injury is unclear, it is well known that an ischemic brain infarct progresses over time (Wei et al., 2006). Therefore, we postulate that the reduction of the infarct area in the transplanted group, compared with the control operated group was induced by reduction of secondary damage in the penumbra area initiated by ischemia and cell death. Cell transplantation may induce certain functional recovery of the brain tissue by endogenous cell mediated effect (Zhao et al., 2002). Our study suggest that intracerebrally injected mES cells survived and migrated into the infarct area from inoculation site and neuroglially differentiated in the ischemic brain area of adult rats.

\section{CONFLICT OF INTEREST}

No potential conflict of interest relevant to this article was reported.

\section{ACKNOWLEDGMENTS}

This article is supported by Namseoul university fund.

\section{REFERENCES}

Arvidsson A, Collin T, Kirik D, Kokaia Z, Lindvall O. Neuronal replacement from endogenous precursors in the adult brain after stroke. Nat Med 2002;8:963-970.

Barone FC, Feuerstein GZ. Inflammatory mediators and stroke: new opportunities for novel therapeutics. J Cereb Blood Flow Metab 1999;19: 819-834

Benedek A, Moricz K, Juranyi Z, Gigler G, Levay G, Harsing Jr LG, Matyus P, Szenasi G, Albert M. Use of TTC staining for the evaluation of tissue injury in the early phases of reperfusion after focal cerebral ischemia in rats. Brain Res 2006;1116:159-165.

Chiba S, Ikeda R, Kurokawa MS, Yoshikawa H, Takeno M, Nagafuchi H, Tadokoro M, Sekino H, Hashimoto T, Suzuki N. Anatomical and functional recovery by embryonic stem cell-derived neural tissue of a mouse model of brain damage. J Neurolo Sci 2004;219:107-117.

Englund U, Fricker-Gates RA, Lundberg C, Bjorklund A, Wictorin K. Transplantation of human neural progenitor cells into the neonatal rat brain: extensive migration and differentiation with long-distance axonal projections. Exp Neurol 2002;173:1-21.

Ide K, Horn A, Secher NH. Cerebral metabolic response to submaximal exercise. J Appl Physiol 1999;87:1604-1608.

Iihoshi S, Honmou O, Houkin K, Hashi K, Kocsis JD. A therapeutic window for intravenous administration of autologous bone marrow after cerebral ischemia in adult rats. Brain Res 2004;8:1-9.

Ikeda N, Nonoguchi N, Zhao MZ, Watanabe T, Kajimoto Y, Furutama D, Kimura F, Dezawa M, Coffin RS, Otsuki Y, Kuroiwa T, Miyatake S. Bone marrow stromal cells that enhanced fibroblast growth factor-2 secretion by herpes simplex virus vector improve neurological outcome after transient focal cerebral ischemia in rats. Stroke 2005;36: 2725-2730.

Jin K, Sun Y, Xie L, Mao XO, Childs J, Peel A, Logvinova A, Banwait S, Greenberg DA. Comparison of ischemia-directed migration of neural precursor cells after intrastriatal, intraventricular, or intravenous transplantation in the rat. Neurobiol Dis 2005;18:366-374.

Kim DY, Park SH, Lee SU, Choi DH, Park HW, Paek SH, Shin HY, Kim 
EY, Park SP, Lim JH. Effect of human embryonic stem cell-derived neuronal precursor cell transplantation into the cerebral infarct model of rat with exercise. Neurosci Res 2007;58:164-175.

Kunlin J, Lin X, XiaoOu M, Maeve B, Alexander M, Botao P, Rose B, Greenberg DA. Effect of human neural precursor cell transplantation on endogenous neurogenesis after focal cerebral ischemia in the rat. Brain Res 2010;1374:56-62.

Lee TH, Yoon JG. Intracerebral transplantation of human adipose tissue stromal cells after middle cerebral artery occlusion in rats. J Clin Neuro 2008;15:907-912.

Lin JH, Weigel H, Cotrina ML, Liu S, Bueno E, Hansen AJ, Hansen TW, Goldman S, Nedergaard M. Gap-junction-mediated propagation and amplification of cell injury. Nat Neurosci 1998;1:494-500.

Liu F, Schafner DP, McCullough LD. TTC, Fluoro-Jade B and NeuN staining confirm evolving phases of infarction induced by middle cerebral artery occlusion. J Neurosci Met 2009;179:1-8.

Modo M, Stroemer RP, Tang E, Veizovic T, Sowniski P, Hodges H. Neurological sequelae and long-term behavioural assessment of rats with transient middle cerebral artery occlusion. J Neurosci Met 2000;104:99109.

Nakatomi H, Kuriu T, Okabe S, Yamamoto S, Hatano O, Kawahara N, Tamura A, Kirino T, Nakafuku M. Regeneration of hippocampal py- ramidal neurons after ischemic brain injury by recruitment of endogenous neural progenitors. Cell 2002;110:429-441.

Omori Y, Honmou O, Harada K, Suzuki J, Houkin K, Kocsis JD. Optimization of a therapeutic protocol for intravenous injection of human mesenchymal stem cells after cerebral ischemia in adult rats, Brain Res 2008;1236:30-38.

Theus MH, Wei L, Cui L, Francis K, Hu X, Keogh C, Yu SP. In vitro hypoxic preconditioning of embryonic stem cells as a strategy of promoting cell survival and functional benefits after transplantation into the ischemic rat brain. Exp Neurol 2008;210:656-670.

Wei L, Han BH, Li Y, Keogh CL, Holtzman DM, Yu SP. Cell death mechanism and protective effect of erythropoietin after focal ischemia in the whisker-barrel cortex of neonatal rats. J Pharmacol Exp Ther 2006;317:109-116.

Zhao LR, Duan WM, Reyes M, Eene CD, Verfaillie CM, Low WC. Human bone marrow stem cells exhibit neural phenotypes and ameliorate neurological deficits after grafting into the ischemic brain of rats. Exp Neurol 2002;174:11-20.

Zuk PA, Zuh M, Mizuno H, Huang J, Futrell JW, Atz AJ, Benhaim P, Lorenz HP, Hedrick MH. Multilineage cells human adipose tissue: implications for cell-based therapies. Tissue Eng 2001;7:209-226. 